\title{
TUNNEL BORING MACHINE DESIGN AND RELIABILITY PARAMETERS OF A DYNAMIC ROCK-INDENTOR SYSTEM
}

The article deals with the calculation of reliability indicators of system dynamics, between the tunnel boring machine and the rock during the tunnel boring of the exploratory tunnel Branisko. The background deals with a design of a tunnel boring machine as a whole where the observed parts are rolling chisels in relation to the length of tunnel boring, as well as physical and technological properties of disintegrated rock.

Keywords: tunnel boring machine, rock disintegration, reliability parameters, maintenance

\section{Introduction}

The theoretical justification and explanation of the processes of disintegration of rocks and the mechanism of their disintegration are based on the theory of elasticity (the area of continuum mechanics) [1,2]. This is because the vast majority of rocks during the mechanical disintegration acts as a quasi-elastic and brittle material and the ongoing processes can be interpreted by the foundations of this theory. However, by formulating new hypotheses and conclusions, the usage of additional simplifications must be considered. This model describes the behaviour of rocks interacting with the tool until disintegration occurs.

\section{Construction of tunnel boring machine}

Full-profile tunnel boring machine (TBM) is a complex set of machinery and equipment units, that allows a mechanical boring into rock mass, creating an opening of a circular shape of a specified size, that is secured against collapse. Tunnel boring machine consists of:

- supporting skeleton,

- tunnel boring head,

- engine,

- telescopic hydraulic press mechanisms,

- transport trailer.

The TBM equipment automatically loads and transports removed rock from the tunnel into the transport trailer. The transport trailer is several tens of meters long. During the extraction this trailer is attached behind the TBM, and is pulled on rails. The transport trailer is equipped with all the distribution and support mechanism that are necessary for continuous and fully balanced operation of the tunnel boring machine [3, 4].
The excavation performance of TBM machine is significantly influenced by the design of the tunnel boring head, of its torque and by the design of rolling chisels. Rolling chisels for TBM are specifically designed for tunnel boring in hard rock conditions.

The performance of installed engine drive depends on the required torque and speed. Torque is significantly influenced by geological conditions. Soft, easily drillable rocks allow by the same chisel pressure a greater penetration. As a result, more rotation resistance requires more torque power than for hard rocks (low penetration). In soft rocks, it is not possible to use the full value of penetration, achieved by pushing force, otherwise it would uneconomically increase the necessary torque parameters. On the other hand, in hard rocks, even at the maximum thrust only a relatively small penetration can be achieved, therefore a relatively small torque is necessary.

In soft rocks the necessary high torque level can be compensated by reducing the number of revolutions. The corresponding high level of torque and thrust must be adapted and all bearings must be sturdily constructed. That ensures sufficient durability and reliability of the entire plant.

Rock disintegration by full-profile tunnelling boring machines is a very complex process. The price for a standard meter length of such underground works is determined by a number of factors. These are: design and operational parameters, construction of disk chisels, chisels deployment at the tunnelling boring head, their shape and material composition, and last the applied tunnel boring regime [5]. So in terms of the total work cost, the process of disintegration especially in its optimal mode throughout the tunnelled section has the most impact, as well as the design of the tunnelling boring machine. Therefore, it is important to collect all important data about the ongoing tunnelling process, about the current mode

\footnotetext{
* Marcela Malindzakova, Jozef Futo

Institute of Control and Informatization of Production Processes, Faculty of Mining, Ecology, Process Control and Geotechnology, TU Kosice, Slovakia, E-mail: marcela.malindzakova@tuke.sk
} 
and machine status. A significant challenge for this kind of monitoring is the rapid transfer of real time data. After proper analysis, the results can be implemented for better control of this challenging process in real time [6-10].

One way to evaluate the effectiveness of the tunnelling boring process is to monitor the reliability indicators of used chisels or reliability of models that take into account the impact of the machine regime on its design elements, depending on the tunnel boring regime.

Reliability indicators used in this article are quantitative. They show the impact of static and dynamic properties of tunnel boring machine-rock system for transition through different geological sections of the gradual attrition of tunnel boring chisels $[3,4]$.

\section{The monitoring of the tunnelling boring indenter - rock system}

Monitoring system for tunnel boring machine allows capturing and storing the following variables: thrust, speed, torque, power and length of extracted rocks (henceforth called extract). In addition to those variables, for this study, also the frequency of chisels replacements was monitored, along with corresponding material composition. Fig. 1 shows a tunnel boring head with roller chisels.

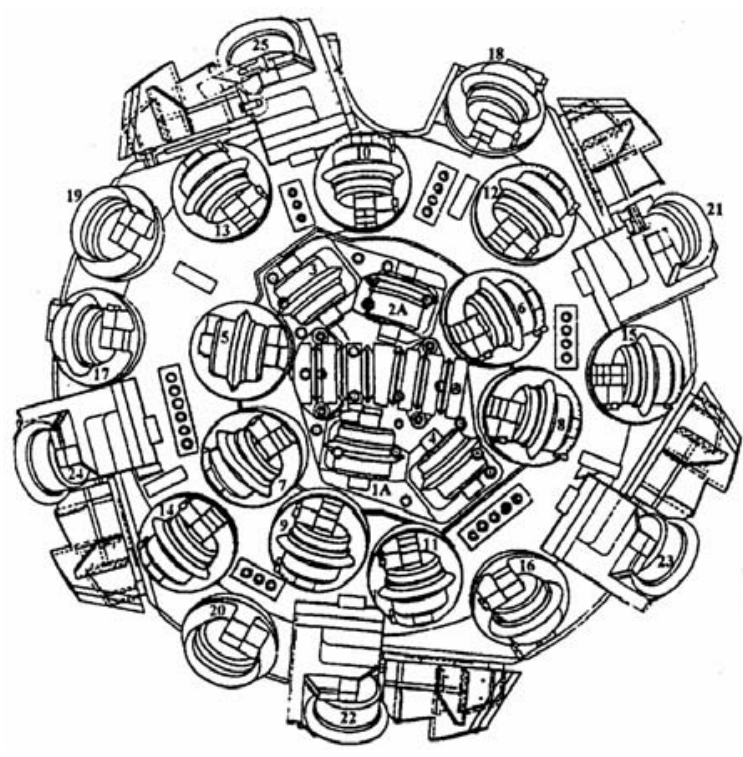

Fig. 1 Tunnel boring head with roller chisels

Based on the values measured during the monitoring of the tunnel boring process we can create models for monitoring of static and dynamic properties of tunnel boring heads. Input variables include the thrust and speed; the output variables include power and torque of the tunnel boring head (Fig. 2).

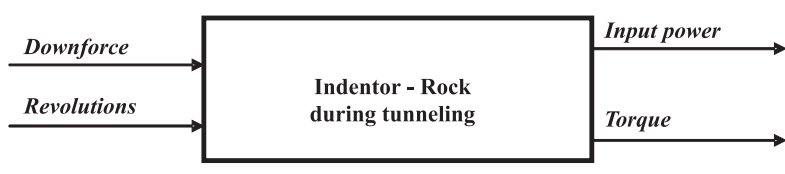

Fig. 2 Process flow diagram of disintegration input / output

The static properties of this system include:

- design parameters of a tunnel boring machine, e.g. dimensions of the head, the installed capacity,

- number and shape of chisels,

- properties of rocks, which are "homogeneous" in different geological sections.

Whilst the static properties of this system during tunnelling do not change, the dynamic properties of this system change over time as they depend on parameters that change during tunnelling.

Changing the parameters affects the technical state of the system and ultimately affects the final price of the tunnelling works. One way to assess the dynamic properties of tunnel boring systems is to investigate the transient characteristics. Examples of these transitions are shown in Fig. 3. It implies not only different torque values, but also the trend [11, 12] and [13].

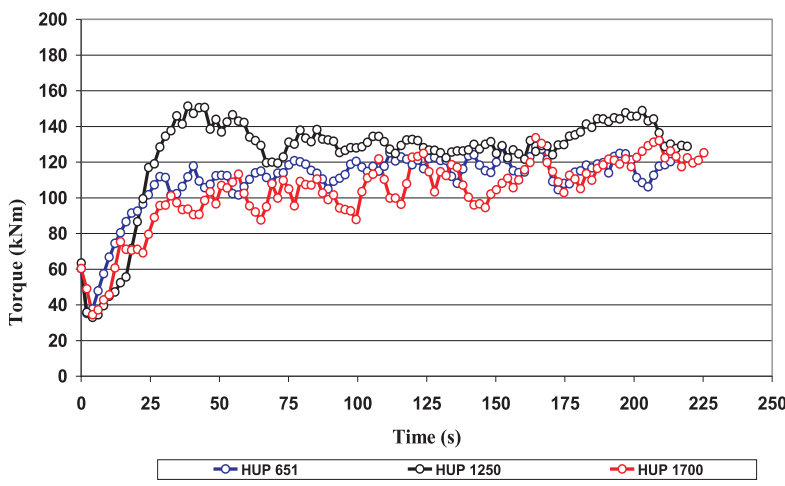

Fig. 3 Trends of transient characteristics in different types of rocks

Based on the transient characteristics it can be assumed that the wear and tear, damage and also the number of replaced rolling chisels will greatly affect the dynamic stress of a tunnel boring head. The trends of rolling chisels replacements across section stations can be observed in Fig. 4, where HUP lines describe drilling in three different geological sections

The replacements begun at a distance of 452 meters from the entrance portal when 2 chisel pieces are replaced and then from 780 meters to 835 meters further 6 chisels had to be replaced. Gradually, at a distance of 958 meters, 18 chisels had to be replaced. After that we can observe a replacements stabilization at the distance of about one hundred meters, followed again by a dramatic increase of replacements at a distance of 1092 meters, when first 
17 and then 30 meters further 9 more chisels had to be replaced. This fact can be described also by reliability indicators such as, for example, by the rate of replacement probability (Fig. 5) or the intensity of replacements (Fig. 6).

Reliability indicators help designers and technologists more accurately determine the time and cause of the damage for the subsequent chisels replacement. There is a number of theories that describe the wear and dulling of rolling chisels, but the values obtained from monitoring can reveal new connections between input variables and the number of replaced chisels [14-17].

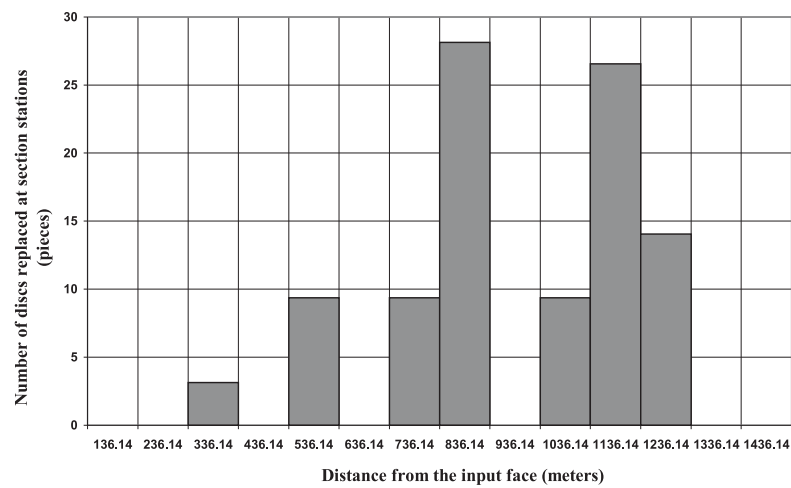

Fig. 4 Number of discs replacements at section stations

Mathematical formulas describing the used indicators are based on the probability theory [18-20]. The statistical estimates of indicators for a failure-free operation, it is not necessary to record the number of chisels $\Delta B_{t}(\Delta T)$ that are damaged in short time $\Delta T$ after time interval $t$.

$$
\Delta B_{t}(\Delta T)=B(t+\Delta T)=B(t+\Delta t)-B(t) .
$$

Because in an estimate the following is valid:

$$
\Delta B_{t}(\Delta T) \cong N f_{E}(t) \Delta T
$$

where $N$ stands for total number of samples, the point estimate $f_{E}(t)$ of the rate of a defects probability in the interval $\langle 0, t\rangle$ given by formula:

$$
f_{E}(t)=\frac{\Delta B_{i}(\Delta T)}{N \Delta T} .
$$

then the replacements intensity can be described by:

$$
\lambda_{E}(t)=\frac{\Delta B_{i}(\Delta T)}{N(t) \Delta T} .
$$

\section{Conclusion}

Life expectancy of rolling chisels or tools usage converted to 1 cubic meter of desintegrated rock is a very significant cost

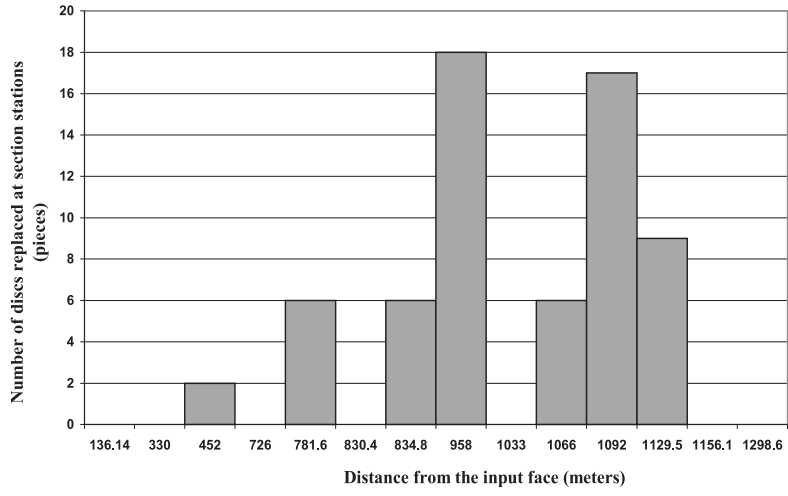

Fig. 5 Drilling distance when chisel replacements at section station occured

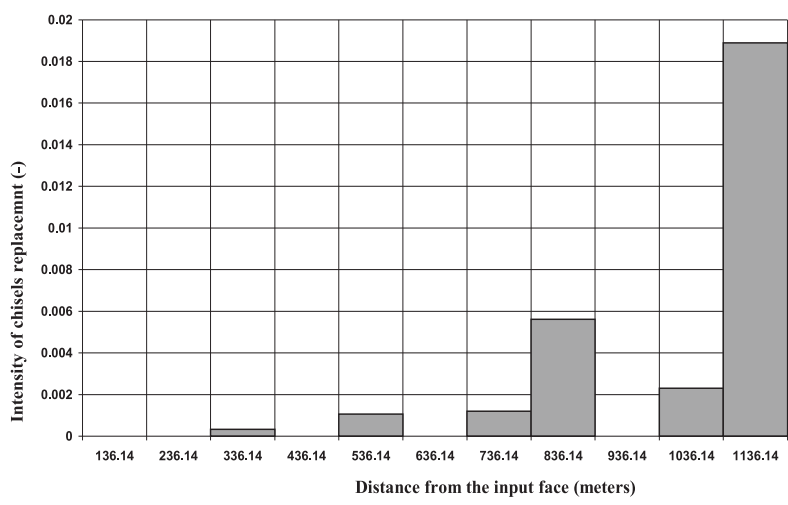

Fig. 6 The intensity of chisels replacements at section stations

characteristic. It affects significantly the total cost of TBM excavation, directly or indirectly:

- the price of used rolling chisels directly affects the cost of TBM excavation,

- indirectly, it causes the loss associated with the necessary downtime needed for replacement of a blunt rolling chisel.

The cost of tunnel boring chisels are mainly influenced by:

- properties of rocks (hardness, abrasion resistance, brittleness)

- shape and diameter of the tunnel boring head

- the required rate of tunnel boring,

- construction of a rolling chisel.

Modern roller chisels have properly sealed and lubricated bearings, which greatly extends their life expectancy. The edge of tunnel boring chisel that is made of carbide can be replaced independently and rolling chisels can be written off after a few replacements of the tunnel boring edge, which significantly reduces the tunnelling costs. The cost of tunnelling boring tool based on the rocks hardness are considerably higher than the figures stated by the Wirth firm in the first half of the 90ies:

- for hard rock (amphibolite, granodiorite) at the tunnel boring speed of 1.5 meter per hour, the price of tunnel boring chisels varies from 7.5 to $10 \mathrm{EUR} / \mathrm{m}^{3}$ of disintegrated rock, 
- for medium-hard rock (sandstone and limestone) at the tunnel boring speed of about 3.5 meter per hour, the price of tunnel boring chisels is about $5 \mathrm{EUR} / \mathrm{m}^{3}$ of disintegrated rock.

For further research it is necessary to pay closer attention to the monitoring of dynamic properties of the rock-indenter system. It is possible, for example, by constructing a suitable simulation model of these dynamic processes, taking into account mainly the wear and damage to chisels on the tunnel boring head. Subsequent description of those experimental processes, implementing suitable mathematical models and resolving the rapid transfer of data problem, could represent a suitable solution for better control and management of this complex process. Also the data obtained in real time provide an opportunity to predict dangerous operating conditions.

\section{References}

[1] KRUPA, V.: Hypotheses, Models, Theories and the Verification of the Full-profile tunneling [Hypotezy, modely, teorie a ich verifikacie pri plnoprofilovom razeni], Dizertation thesis, Kosice, UGt SAV, 1998.

[2] KRUPA, V., PINKA, J.: Rock Disintegration [Rozpojovanie hornin], Stroffek, Kosice, 1997.

[3] KLEPSATEL, F. et al.: Construction of the Tunnels in the Rock [Vystavba tunelu ve skalnich horninach], Vydavatelstvi Jaga group, v. o. s., Bratislava, 2003, ISBN 80-88905-43-5.

[4] LAZAROVA, E., KRUPA, V.: Experiences from Full-profile Exploration Excavation of Tunnels construction [Skusenosti z plnoprofiloveho razenia prieskumnych stolni pre tunelove stavby], Acta Montanistica Slovaca, vol. 11, 2006, special No. 2, pp. 330-334, ISSN 1335-1788.

[5] FUTO, J., IVANICOVA, L., KREPELKA, F.: Statistical Evaluation of Reliability of Disc Roller Bits on Tunnel Boring Machines. Proc. of $34^{\text {th }}$ Seminar ASR 09 Instruments and Control, 2009, VSB TU : Ostrava, 2009. p. 16, ISBN 978-80-248-2011-8.

[6] BARANOVA, V.: Measurement and Evaluation of Parameters to Support the Management of Steel in Oxygen Converters [Meranie a vyhodnotenie parametrov na podporu riadenia vzroby ocele v kyslikovych konvertoroch], Kosice, Technicka univerzita, F BERG, Bachelor thesis, 2008.

[7] BARANOVA, V.: The Impact of Quality of Input Material for the Converter Process [Vplyv kvality vstupnych surovin na konvertorovy proces], Kosice, Technicka univerzita, F BERG, Diploma thesis, 2010.

[8] BENKOVA, M.: Quality Assurance Processes [Zabezpecovanie kvality procesov], Kosice, Technicka univerzita, F BERG, 2007.

[9] BENKOVA, M., FLOREKOVA, L., BOGDANOVSKA, G.: Variability of Quality Parameters and the Loss Function [Variabilita parametrov kvality a stratova funkcia], In: Acta Montanistica Slovaca, vol. 10, No. 1, 2005, pp. 57-61.

[10] FUTO, J., IVANICOVA, L., KREPELKA, F.: Hydraulics and Pneumatics - parts 1-2 [Hydraulika a pneumatika 1-2], 2010, pp. 9-13.

[11] KACUR, J., LACIAK, M., DURDAN, M.: Measurement of Relevant Variables in the Process of Underground Coal Gasification [Meranie relevantnych velicin v procese podzemneho splynovania uhlia], AT\&P journal, 2010, vol. 17, No. 11, pp. 51-55, ISSN 1335-2237.

[12] KRUPA, V., LAZAROVA, E.: Assessing the Reliability of Rolling Disk Chisels Full-Profile Tunneling Machine Drilling of Exploration Gallery for Tunnel Tubes [Hodnotenie spolahlivosti diskovych valivych dlat plnoprofilovych raziacich strojov pri razeni prieskumnych stolni pre tunelove rury], Q magazin, internetovy casopis o jakosti. Ostrava: VSB-TU, 2009, vol. 4, fmmi10.vsb.cz/639/ magazin.htm, ISSN 1213-0451.

[13] LESSO, I., FLEGNER, P.: Specification of Symptom Process of Disintegration of Rocks by Rotary Drilling for the Purpose of Process Management [Specifikacia priznakov procesu rozpojovania hornin rotacnym vrtanim pre ucely riadenia procesu], In: Sbornik vedeckych praci Vysoke skoly banske - Technicke univerzity Ostrava : Rada stavebni, vol. 9, No. 2, 2009, pp. 155-165, ISSN 1213-1962.

[14] HOROVCAK, P., TERPAK, J.: Web Services in Comparison with Other Technologies. In: ICCC 2004: Proc. of intern. Carpathian control conference, Zakopane, Poland, 2004, Krakow, ISBN 83-89772-00-0.

[15] KACUR, J., LACIAK, M., DURDAN, M.: Remote Monitoring and Control of the UCC Process. In: ICCC 2011, Proc. of the 12 Intern. Carpatian Control Conference, Velke Karlovice, Czech Republic, pp. 180-184, ISBN 978-1-61284-359-9.

[16] KOCI, P.: Computer Science [Vypocetni technika]. VSB-TUO,1. vyd. Ostrava, VSB-TU Ostrava, 2007, ISBN 978-0-248-1515-2.

[17] TUMA, J., WAGNEROVA, R. FARANA, R. LANDRYOVA, L.: The basis of automation [Zaklady automatizace], 1. vyd. Ostrava, VSB-TU Ostrava, p. 280, ISBN 978-80-248-1523-7.

[18] MYKISKA, A.: Reliability of Automation Systems [Spolehlivost automatizacnich systemu], CVUT, Praha, 1996, ISBN 80-01-01466-5.

[19] O'CONNOR, P., D., T. et al.: Practical Reliability Engineering, John Wiley \& Sons, Chichester, Wiley, 2006, ISBN 978-0-470-84462-5.

[20] PAVLicKOVA, M., BOGDANOVSKA, G.: The Position of Metrology and Measurement to Support Quality Products [Pozicia metrologie a merania pre podporu kvality vyrobkov], Manazment $v$ teorii a praxi: On-line odborny casopis o novych trendoch $v$ manazmente, vol. 3, No. 4 (2007), pp. 79-85. 